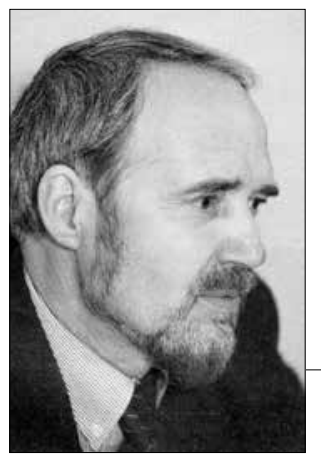

https://doi.org/10.24101/logos.2017.60

ANTANAS ANDRIJAUSKAS

Lietuvos kultūros tyrimo institutas

Lithuanian Culture Research Institute

\title{
BABILONO CIVILIZACIJA \\ LYGINAMOSIOS ANALIZĖS PERSPEKTYVOJE
}

\author{
Babylonian Civilization in the Perspective \\ of Comparative Analysis
}

\section{SUMMARY}

The article provides a comparative discourse on the ancient Babylonian civilization which emerged in Mesopotamia during the decline of Sumerian civilization. The author is especially interested in its genesis and complex relations with neighboring cultures and nations. He focuses on Babylonian religion, culture, administration and social institutions. Much attention is also paid to the Babylonian achievements in astronomy, mathematics, medicine, law, architecture, visual arts and literature.

\section{SANTRAUKA}

Straipsnyje lyginamuoju aspektu aptariama viena seniausių Mesopotamijos regione po šumerų suklestejjimo iškilusi Babilono civilizacija. Autorių domina ne tik specifiniai jos genezès aspektai, santykiai su anksčiau čia gyvavusiomis ir lygiagrečiai besiskleidžiančiomis kitomis civilizacijomis bei tautomis. Daugiausia dèmesio skiriama Babilono civilizacijos religinès sistemos, kultūrinio fondo, valstybès valdymo aparato, socialinės organizacijos aptarimui. Taip pat daug dėmesio skiriama laimejjimams astronomijos, matematikos, medicinos, teisès, architektūros, vaizduojamosios dailès ir literatūros srityse.

\section{MESOPOTAMIJOS GAMTINIŲ SĄLYGUৃ YPATUMAI IR BABILONO CIVILIZACIJOS IŠTAKOS}

Ieškant seniausių miesto tipo civili- ̌erdyje esančią ir palankiomis ūkinei zacijų ištakų, žvilgsnis pirmiausia kryps- veiklai sąlygomis išsiskiriančią Mesopo-

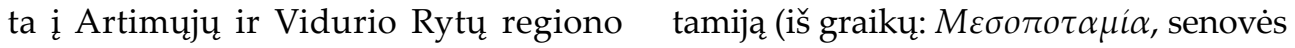


persu Miyanrudan - tarpupis, arba aramejjų Beth-Nahrin - dvi upès), kuri aprèpia dabartinès Irako valstybès ribas. Tai buvo stambiausias Artimuosiuose ir Vidurio Rytuose lygumų regionas su didžiuliais labai palankios žemdirbystei drèkinamos žemès plotais. Čia esantys vandeningų Tigro ir Eufrato upių derlingi slèniai yra tas židinys, kuriame pradeda skleistis seniausios vakarines Afro-Eurazijos civilizacijos. Mesopotamijos teritorija šiaurejje ribojasi su Armènijos plokštikalnejje iškylančiais aukštais kalnais, kurie sulaiko šalto oro srautus iš šiaurès, pietuose siekia Persijos ịlanka, Rytuose ribojasi su Irano kalnais, o vakaruose - su Arabijos dykumų erdvèmis ir Sirijos aukštikalnėmis. Šiame strategiškai svarbiame Vidurio Rytų tarptautinių komunikaciju ir prekybos keliu susikirtimo regione formuojasi galingos senovès pasaulio valstybės ir imperijos: šumeru, Akado, Senoji Babilonijos, Naujoji Babilonijos, arba kitaip vadinama chaldeju karalystè, Senoji, Vidurinè, Naujoji Asirijos karalystès ir Mitanija.

Kitaip nei gamtinių kliūčių izoliuotas Egiptas, į kurio teritoriją galima pakliūti arba iš Nubijos pusės, kur yra Nilo aukštupys, arba iš jo žemupio, šumeru apgyvendinta pietinè Mesopotamija tokių palankių apsaugai nuo nomadų i̇siveržimų gamtinių kliūčių neturi. Kitas išorinis Mesopotamijos ir Egipto civilizaciniu erdvių panašumas - Nilo ir Tigro bei Eufrato upių baseinuose esančios intensyvios žalios spalvos stichijoje skęstančios didžiulès pusdykumių ir dykumų erdvès. Kaip ir šumerų apgyvendintos Tarpupio teritorijos panašios i Egipto Nilo upés baseino derlingos žalumos juos- tas. Iš tikrųjų derlingiausią Mesopotamijos teritorijos dali sudaro protakų išvagota aliuvinė lyguma tarp dviejų didžiųjų Tarpupio upių. Iš šiaurèje ir rytuose esančių kalnų upių srautų nuolatos atnaujinama sąnašinè dirva yra labai derlinga, tačiau sèkmingam pasèlių augimui nuolat grasino staigūs upiu potvyniai arba sausros. Upių vandens lygis čia kildavo staiga, net dvigubai dažniau nei Nilo potvyniai, kurių čia buvo net po aštuonis kartus per metus, juolab kad potvyniai greitai apsemia lèkštus upių krantus. Taigi šiai vietovei būdinga išskirtinè irigacinių sistemų plètotè, ypač statybos pylimu, dambų ir kanalų, kurie apsaugo žemdirbystei skirtus laukus nuo potvynių. Pietinèje karščiausios saulès deginamoje Mesopotamijos dalyje jau nuo senovès taikomos îvairios dirbtinio drèkinimo sistemos. Ju atsiradimas Mesopotamijoje yra datuojamas 6-5 tūkstantmečių pr. m. e. sandūra, tai yra mažiausiai tūkstantmečiu anksčiau nei Egipte.

Seniausios gyvenvietès Mesopotamijos teritorijoje archeologu aptinkamos aukštesnèse vietovėse, viduriniojo paleolito epochoje apie 5500-5000 m. pr. m. e. Per derlingus Tigro ir Eufrato upių slènius nuo seniausių laikų eina svarbūs Senojo pasaulio prekybos ir tautų migracijos keliai, kurie ir paskatina pirmos pasaulyje miesto tipo civilizacijos atsiradimą. Šios civilizacijos užuomazgos bręsta lètai, žingsnis po žingsnio atskleidžiant vis tobulesnes galimybes žemdirbiui ūkininkauti minkštoje ir derlingoje sąnašinèje aliuvinëje dirvoje. „Mesopotamija, - rašo kanadiečių civilizacijos teoretikas Williamas Hardy McNeelas, yra Vidurio Rytuose didžiausia drèkina- 
ma upių lyguma, išsidèsčiusi greta žemdirbystès užgimimo centrų. Šis faktas tikriausiai ir sudarè palankiausias sąlygas civilizacijos užgimimui" (McNeill, Hardy 1991: 65).

Iš tikrujuc čia ilgai ir lètai bręsta įvairios žemdirbystès formos, o nuo IV tūkstantmečio pr. m. e. vienas kitą keičia šumerų, akadiečių, babiloniečių, asirų, medų, persų ir kitų ši regioną valdžiusių tautų sukurti valstybiniai dariniai. Mesopotamijos gyventojai nuo neatmenamų laikų palaiko kultūrinius ir ekonominius ryšius su Egiptu, Indija, o per Oronto slèni - su Finikija ir Palestina. Tūkstantmečių tèkmëje Mesopotamijos valstybių gyventojai - šumerai, akadiečiai, babiloniečiai, asirai, chaldejjai, persai - aktyviai kuria šio regiono kultūros vertybių ir simbolių pasaulį. Būtent čia ir išryškèja savotiškas lūžis civilizacijos istorijoje, kai i civilizacini procesą aktyviai izsitraukus šumerams, jų sukurta unikali civilizacija stebètinai greitai suklesti.

Dèl tolesnio dèstymo aiškumo turime imtis esminès skirties tarp universalesnio civilizacinio darinio, vadinamo „Mesopotamijos civilizacija", ir siauresnio apimtimi ir trukme - „babiloniečių civilizacijos", kuri reprezentuoja ankstyvąą Tarpupio civilizacinès erdvès formavimosi dali. Joje iškyla pirmoji ir seniausia miesto tipo civilizacija, šumeru civilizacija, kurios kultūros tradicijas pratęsè tame pačiame regione vèliau išsiskleidusi Babilono civilizacija.

Mesopotamijos civilizacijos, aprèpiančios apytikriai dabartinio Irako teritorija, gyvavimo pradžią galima datuoti apie 3500 m. pr. m. e., kai čia iškyla pirmas reikšmingas šumerų civilizacijos centras - miestas-valstybe Urukas, o pabaigą 559 m. pr. m. e., kai Tarpupio regioną užkariauja ir jo civilizacinès raidos krypti keičia galinga Persijos imperija. Per ši beveik 3000 metų istorini laikotarpi Tarpupyje viena kitą keičia šumeru, akadų, babiloniečių, asirų ir daugelio kitu Vidurio Azijos regione gyvavusiu tautų sukurtos valstybès bei civilizacijos. Šio regiono civilizacinių sistemų nestabilumą iš dalies lèmè regiono geografinè padètis svarbių tarptautinių prekybos kelių sankryžoje ir tai, kad šią lygumų ir atvirų erdvių teritoriją, nesaugomą natūralių gamtinių kliūčių, lengviau užkariaudavo klajoklių tautos.

Pasak rašytinių šaltinių ir archeologinių duomenu, pietinejje Mesopotamijos regiono plokščios lygumos dalyje, kurios klimatas dabar karštas ir sausas, šumeru civilizacijos užgimimo ir Bibilono sklaidos metu buvo gausu augmenijos. Šioje palankioje žemdirbystei teritorijoje maždaug tūkstantmečiu anksčiau nei kituose didžiuju upių civilizacijos centruose regime besiplètojančias ūkinès sistemos užuomazgas su miestais, komunikacijos arterijas, aprépiančias šią daugmaž vientisą civilizacinę erdvę, kuri, kitaip nei šiaurinė Mesopotamija, nèra atskirta nuo supančio pasaulio jokiomis ženklesnemis geografinèmis kliūtimis. Šioje nedidelejje teritorijoje aplink Tigro ir Eufrato žemupi, netoli jų laivybai tinkamų upių žiočių, ir užsimezga seniausia šumerų civilizacija, apie kurios egzistavimą pasaulis sužinojo tik kiek daugiau nei prieš 150 metų filologijos specialistų dèka. Būtent nuo šios šumeru civilizacijos prasideda didžiuju Senojo pasaulio civilizaciju paradas. Jos pirmeiviškumas, daugybė 
svarbių vèlesnei civilizacijos istorijai atradimų turi ne tik didžiuli poveiki minètoms Mesopotamijos regione gyvavusioms tautoms, tačiau ir daugybei kitų didžiųjų milžiniškoje Afro-Euroazijos civilizacinèje erdvèje išsiskleidusių sociokultūrinių organizmų.

Po Akado imperijos žlugimo Mesopotamijos regione ir nomadu nuniokotiems ištuštejjusiems šumeru miestams išgyvenant gilią krizę, pradeda vyrauti dvi pagrindinès semitiškos kilmès (semitai - kalbų ir tautų šeima, kildinama iš biblinio Nojaus sūnaus Semo mitinių palikuonių) valstybès pietuose - semitiškų amoritu genčių valdomas Babilonas ir kiek vèliau šiaurinèje šio regiono dalyje iškilusi Asirijos imperija. Tarp šių dvieju galios centru vyksta nuolatinè kova dèl hegemonijos Mesopotamijos regione. Minètú valstybiu santykiu istorija yra tokia sudetinga, permainingai besikeičianti, kad susidaro ispūdis, jog kai kuriuos Mesopotamijos regiono civilizacines raidos procesus tikslinga nagrineti artimiau siejant Babilono ir asiru civilizaciju istorijas.

Pirmiausia, kaip minejome, iškyla šumerų civilizacijos laimèjimus tiesiogiai perèmusi antroji didinga Mesopotamijos regione atsiradusi Babilono civilizacija. Jos gyvavimo kelias buvo išvagotas daugybės dramatiškų sukrètimų. Ankstyvasis šios civilizacijos gyvavimo ir sklaidos tarpsnis paprastai civilizacijos istorijos tyrinejjimuose yra vadinamas Senaja $\mathrm{Ba}$ bilonijos karalyste (1894-1595 m. pr. m. e.). Šios naujos civilizacijos pirmaisiais kūrèjais tampa galingos, po akadų imperijos žlugimo Mesopotamijos teritorijoje iškilusios Senovès Babilono karalystès gyventojai, kurie plètoja šumeru ir akadų kultūros tradicijas. Minètų dviejų Vidurio
Azijos regiono civilizacinių tradicijų tęstinumas yra natūralus, kadangi tarp naujos valstybès gyventojų etniniu požiūriu viešpatauja šumeru ir akadų palikuonių mišinys, kuris kasdieniame gyvenime vartoja akadų, vèliau semitiškas amoritų ir aramëjų kalbas. Po semitiškų genčių amoritų îsiveržimo į Akado imperiją Mesopotamijos teritorija vèl suskyla ị miestus-valstybes, tarp kurių dèl hegemonijos rungiasi Isinas, Ešnūna, Maris, Ašūras ir kiti. Tačiau netrukus Mesopotamijos civilizacinëje erdvejje iškyla iki tol menkai žinomas miestas Babilonas (,Dievo vartai“), kuris yra strategiškai svarbioje vietoje, ties Tigro ir Eufrato suartejimu, i pietus nuo dabartinio Bagdado (žr. Margueron 2001: 334-336).

Sparčiai augantis ir plečiantis savo ekonominę bei karinę itaką ìvairiomis kryptimis Babilono miestas šimtmečiams tampa šerdimi naujos visą Mesopotamiją apjungusios civilizacijos, kuri dominuoja Mesopotamijos regione per tūkstanti metú. Svarbius duomenis apie Babiloną pateikia Herodotas, kuris rašo, kad šis miestas yra „pastatytas didelëje lygumoje, kompaktiškas, kiekviena jo kraštinè lygi 120 stadijų. Toks yra Babilono dydis. Kiek mums žinoma, nè vienas kitas polis nèra taip sutvirtintas kaip jis" (Herodotas 1988: 76). Šio naujo stiprejjančios valstybès centro kūrejjais ir valdovais tampa apie $300 \mathrm{~m}$. ši regioną valdanti Hamurabių dinastija. Sumanus šeštasis šios babiloniškos dinastijos valdovas Hamurabis (Hamurapis) (XVIII a. pr. m. e.) nuosekliai kaupia jo galios instrumentu tampančius ekonominius ir karinius išteklius. Sukūręs stiprią valstybę, jis išplečia savo valdžią nuo Persijos ilankos iki Zagro kalnų. Netrukus Hamurabis antrą 
kartą suvienija visą Mesopotamijos teritoriją ir îkuria Senąją Babilonijos karalystę, kuri jam valdant pasiekia didžiausios galybès ir teritorinès ekspansijos tarpsnį. Šiuo babiloniečių civilizacijos klestèjimo laikotarpiu jos kultūra išsiskleidžia įvairiomis spalvomis ir sèkmingai gyvuoja nuo 1800 iki 1600 m. pr. m. e. Itin reikšmingu šio tarpsnio Babilono civilizacijos raidos veiksniu, anot H. W. F. Saggs, tampa „naujų administracinio valdymo metodu, pavyzdžiui, centralizuoto valdymo iš vieno miesto, įvedimas. Tai vèliau ateityje turès toli siekiančias pasekmes" (Saggs 1965: 14).

Šalies valdovas Hamurabis perima daugeli Sargono įdiegtų imperijos socialinès organizacijos principų ir išleidžia garsujij, vieną seniausių žmonijos rašytinès teisès paminklų - îstatymų rinkinị, iejusi i i istoriją "Hamurabio kodekso" vardu. Šis didžiulès apimties tekstas iškalamas dantiraščiu dviejų metrų aukščio akmeninejje steloje ir tampa vienu svarbiausių dantiraščiu šifruotojų tyrinejjimo objektų. Minètos stelos viršuje pavaizduotas Hamurabis, rankos gestu sveikinantis sedinti vieną pagrindinių babiloniečių dievų panteono atstovų saulès dievą Šamašą.

Hamurabio kodeksas yra vienas svarbiausių ankstyvųu ci civilizacijų ìvairius teisinius gyvenimo aspektus reglamentuojančių îstatymų kodeksų. Jo pradžioje pabrèžiamas pagrindinis tikslas - ittvirtinti teisingumo principus šalyje. Tai aiškiai struktūruotas teisinès minties dokumentas, kuriame straipsnis po straipsnio apibūdinami îvairūs baudžiamosios teisès, teismo proceso, prekybos, gamybinès veiklos, žemès ūkio, gyvulininkystès, šeimos teisès, nuosavybès, paveldejjimo teisės, karių, vyrų, moterų, vaikų, vergų santykių ir kiti teisiniai aspektai. Baudžiamoji teisè grindžiama adekvataus atpildo principu ,akis už aki, dantis už dantị“. Aptariamo kodekso tekstas pateikia daug svarbių žinių apie teisinę ir socialinę to meto visuomenès sandarą. Viešpatauja patriarchalinè šeimos samprata, kai šeimos galva yra tèvas, kuriam turi paklusti kiti nariai. Iš čia kyla vyrų dominavimas socialiniuose santykiuose, jų ir vyriausių sūnų pirmenybė paveldèti turtą. Kodeksas pripažista ir moteru teises. Jos galëjo dalyvauti visuomeniniame gyvenime, užimti kai kuriuos valdžios postus. Teisynas taip pat detaliai reglamentavo kreditoriu elgesi su skolininkais, daugybės šventyklas ir valdovų rūmus aptarnaujančių valstybinių ir privačių vergų teises.

Kita vertus, Hamurabis itin daug dèmesio skiria valstybès valdymo aparato kūrimui, jo tobulinimui, griežtai biurokratinio aparato kontrolei. Šio valdovo valdymo metu smarkiai stiprèja plačius tarptautinius prekybos ryšius užmezgęs turtingiausių Babilono prekybininkų sluoksnis. Tarptautiniai prekybiniai ryšiai valdovo iždui krauna didžiulius pelnus. Imperijai trūksta daugelio jos galiai didinti būtinų strateginių žaliavų, kurios buvo atvežamos iš daugelio artimų ir tolimų šalių. Suvokdamas prekybinių mainų svarbą, valdovas visokeriopai skatina tarptautinejje prekyboje paklausių vietos amatininkų dirbinių ir kitų prekių gamybą. Taip keičiasi ne tik žemés ūkio produktų dalies svoris valstybès ekonomikoje, tačiau ir turtèja pagrindiniai šalies miestai bei prekybos centrai.

Babiloniečiai savo biurokratines valstybès valdymo struktūras ir politeistinès 
religijos dievų kultus perėmè iš anksčiau šiame regione viešpatavusių šumeru, tačiau savuosius dievus jau vadino kitais vardais. Ju pagrindinių dievu panteonas išsiskyrè vaizdinių pavidalu įvairove: vieni dievai buvo vaizduojami kaip žmonės ivairiais antropomorfiniais pavidalais, kiti - kaip abstraktūs kosminių objektu simboliai (saulès disko, pusmènulio ir kt.). Babilono dievų panteone besąlygiškai viešpatauja nuo XVIII a. pakeitęs pasaulio kūrejją Enlili šumeriškojo AmarUtu analogas - aukščiausias pradžioje Saulès, o vèliau perkūno, visatos ir žmonijos kūrëjas, šviesos ir gyvybès dievas Mardukas. Babiloniečiu dailëje jis buvo vaizduojamas kaip barzdotas vyriškis ilgu drabužiu, cilindro formos karūna, su valdžios ženklais kairèje ir rimbu dešinëje rankoje. Babilono civilizacijos saulèlydyje jis buvo vadinamas tiesiog Belu $(\mathrm{Bel})$ - „viešpačiu“. Kiti svarbiausi Babilono religinio panteono dievai: Šamašas - Saulès, Ištare (Astartè), ikūnijanti Venera, - meilès. Babilono miestą globojančiu pagrindiniu dievu buvo Mardukas, kuriam šlovinti buvo pastatyta didinga šventykla su didžiuliu 7 aukštu $90 \mathrm{~m}$ aukščio bokštu, vadinamuoju zikuratu, kuris iejjo i̇ žmonijos kultūros istoriją legendinio „Babelio bokšto" pavadinimu.

Hamurabio dinastijos saulèlydyje prasideda vadinamasis tamsusis Babilono istorijos laikotarpis (XVI-XII a. pr. m. e.), apie kurị iki nūdienos rašytiniuose šaltiniuose išliko mažai žinių. Šiam tarpsniui būdingas ženklus regiono ekonominis nuosmukis, kuri sąlygojo išoriniu genčių ir tautų ekspansija: įsibrovè hetitai, spaudę valdančias kasitu gentis, kurios išstūminëjo anksčiau kraštą užkariavusius elamitus. Kasitų dinastija valdè
Pietų Mesopotamija, o asirai jau sparčiai plètė savo ịtaką šiaurès Mesopotamijoje. Maždaug 1595 m. pr. m. e. Babilono galią palaužè ir sostinę užèmè karingi turtų ištroškę hetitai. Dar iki Mesopotamijos užkariavimo minètos gentys buvo neabejotinai paveiktos šimtmečiais šiame regione gyvavusių kultūros tradicijų: panašios buvo valdymo formos, socialinès hierarchijos principai, todèl šie užkariavimai nesąlygojo reikšmingu civilizaciniu virsmu Babilono istorijoje. Čia išliko didelè žynių sluoksnio įtaka, šventyklos, ūkininkavimo formos, architektūros, vaizduojamosios dailès, literatūros tradicijos. Vèliau stiprejjantį Mesopotamijos politinès ir kultūrinès dezintegracijos procesą sustabdo galinga Asiru imperijos ekspansija, kuri veda i trečią Mesopotamijos suvienijimą ir ilgą Asirų imperijos su sostine Ašure viešpatavimo laikotarpi (X-612 m. pr. m. e.), kuriuo išryškèjo daug specifiniu šios civilizacijos kultūrinei raidai būdingu tendenciju (apie tai kalbėsime Asirijos civilizacijai skirtame skyriuje vèliau).

Babilono karalius, vadovavęs sukilimui prieš nusilpusią Asirija, Nabopalasaras (626-605 m. pr. m. e.), išstūmęs užkariautojus ir $612 \mathrm{~m}$. pr. m. e. sugriovęs Asirijos sostinę Ninevèją savos valstybès sostinę sugrąžina į Babiloną. Jis vèl suvienija Mesopotamijos teritorijoje gyvavusius miestus-valstybes ir su Midija (Medija) pasidalija didžiules Asirijos imperijos valdas. Jos griuvèsiuose sukuria Naujają Babilono arba kitaip vadinamą chaldèjų karalystę, kuri tampa svarbiu galios, ekonomikos ir kultūros centru Vidurio Rytuose. Tarp 612 ir 539 m. pr. m. e. persų užkariavimo Babilono miestas išgyvena savo galios ir kultūrinio 
atgimimo periodą. Tai buvo ketvirtasis ir paskutinis Mesopotamijos suvienijimas. Taip prasideda naujas neilgas Babilono kultūros didybès tarpsnis: klesti prekyba, amatai, mokslas, architektūra, ivvairios literatūros ir meno sritys.

Tačiau šios civilizacinès erdvès išplètimas ir galutinis suvienijimas siejamas su dviem garsiausiais ir galingiausiais šio laikotarpio valdovais Nabuchodonosaru I ir II, kada Naujoji Babilono karalystė pasiekia ekonominès ir politinès galios epogeju: suklesti prekyba, amatai, mokslas, architektūra ir ịvairios literatūros ir meno sritys.

Didžiausią galybę valstybè pasiekè valdant Nabuchodonosarui II, kuris ženk- liai praplečia savo valstybės, pretenduojančias būti imperija, valdas. Ji aprèpia teritoriją nuo Tigro ir Eufrato aukštupio iki žiočiu Persijos įlankos pakraščiuose, vakaruose su plačiu ruožu prie Viduržemio jūros: tai dabartinès Irako, Sirijos, Palestinos ir Izraelio teritorijos, besiribojančios su Egipto civilizacijos erdve. Jis ijungia i savo imperiją Palestina, Sirija, Finikija, užima Jeruzalę, Tyrą. Nabuchodonosaro II įsakymu didumas žydų tautos buvo keliais etapais išvaryta į Mesopotamiją. Šie istorijos epizodai gerai pažĭstami iš biblinių tekstų. Klestinčią Babilonijos valstybę sužlugdo Persijos valdovas Kyras, kurio kariuomenè užgrobia šalį.

\section{KULTÜROS IR MENO SAVITUMAS}

XIX a. pr. m. e. ịsigalèjus pirmajai Babilono dinastijai (1894-1595 m. pr. m. e.), Mesopotamijoje suklesti Senojo Babilono kultūra ir prasideda akadų kalba rašomos semitu literatūros epocha. Buvo sukurtas babiloniškas Gilgamešo epo variantas, daug ivvairiu poetinių tekstų. Babiloniečiai su didžia pagarba žvelgė i šumeru kultūros tradicijas. Šumeru kalba ilgą laiką buvo šios šalies gyventojų sakralinè ir literatūrinè kalba. Daugelis šumeru valstybëje susiformavusių estetiniu pažiūrų, meno kanonų bei stilistinių bruožų, tik nežymiai pakitę, išliko babiloniečių kultūroje. Lygindami šumerų ir babiloniečiu tekstus estetiniu aspektu, matome, jog šumeru estetiškumo samprata glaudžiau susijusi su ritualine kultūra, archajiniais mitologiniais ir totemų ivaizdžiais, dievu pasauliu, o babiloniečiu estetinèse pažiūrose, nepai- sant stiprios šumeru tradicijos itakos, daugiau hedonizmo ir humanistiniu motyvų. Žmogui, suvokusiam autonomiškumą kosminių, gamtos stichiju, dievu atžvilgiu, tampa svarbūs jo paties individualūs bruožai. Jis atsigręžia i̇ save, ì savo dvasios pasauli. Epinèje babiloniečių literatūroje ir meilès poezijoje apdainuojama žmogaus jausmu galia.

Svarbiausiu babiloniečių estetiniu pažiūru pažinimo šaltiniu tampa Gilgamešą aukštinantis epas. Babiloniečiai perèmé pagrindinius šumeru poemos apie Gilgamešą motyvus ir išplètojo juos i savitą daug spalvingesni pasakojimą. Daugelis pagrindiniu siužeto liniju ir veikiančių asmenu išliko, tačiau kitoks pagrindinio epo herojaus, Uruko miesto valdovo Gilgamešo, paveikslas. Babiloniškoje epo versijoje vyrauja ne abstraktūs, nutolę nuo kasdienių žmonių rūpes- 
čių dievai, o gyvas, kenčiantis, nepasotinamų aistrų žmogus, ištikimas savo draugui Enkidu. Babilono herojaus vaizdinys daug sudetingesnis, laisviau aprašinejjami jo gyvenimo epizodai.

Babiloniškoje grožio sampratoje išliko šviesos ir spindesio estetikos elementu, kurie jau skleidžiasi ne tik dieviškojo, tačiau ir žemiškojo grožio plotmejje. Moters grožis asocijuojasi ne tik su vaisingumu, apkūniomis formomis, tačiau ir su skaistumu, spindesiu, tyru vandens srautu. Vyriškojo grožio sampratoje šumeru estetinè tradicija išlieka gyvybingesnè. Kaip ir šumeru tekstuose, vyriškas grožis babiloniečiu epinejje literatūroje pirmiausia siejasi su jëga, gaivališkumu, stiprumu, vyriškomis galiomis. Fragmente, apibūdinančiame Gilgamešo groži, sakoma taip: „Gražus jis kaip vyras savo vyriškom galiom,/ Skleidžia geismą aplink visas kūnas,/
Daugiau už tave jisai turi galybès,/ Sau ramybès neranda dieną ir naktį!" (Senoves Rytu poezija 1991: 112)

Babiloniečių tekstuose susilpnejja ritualinė kultūra ir žynių cenzūra, daugèja pakantumo žmogaus silpnybėms ir auga hedonistinės estetikos įtaka. Atsiranda nerūpestingas ir linksmas cimbolų ir arfų garsų pasaulis: „Grožiu pasileidèlès garsios:/ Geismo pertekę, siūlo malonę" (ten pat). Vienas Gilgamešo epo personažų tokiais žodžiais apibūdina žmogaus paskirtį: „Tu, Gilgamešai, pilvą pasotink,/ Dieną naktị būk pilnas linksmybès,/ šventę surenk sau kas diena,/ Dieną nakti groki ir šoki!/ šviesūs tebūnie tavo rūbai,/ švarūs plaukai, vandeniu prauskis,/ žiūrèk, kaip vaikelis ranką tau laiko,/ Savo glamonemis džiugink draugužę, / Tiktai čia žmogaus paskirtis glūdi!" (ten pat: 149)

\section{BABILONIEČIŲ CIVILIZACIJOS LAIMĖJIMAI}

Šumerams būdingas kūrybiškumo genas dèl jų maišymosi su kitu gretimu tautu atstovais vis dèlto išliko ryškus ir babiloniečiu kultūros laimèjimuose. Babilonas savo klestèjimo metu buvo vienas pagrindiniu senojo pasaulio miestu, išsiskiriančiu unikalia urbanistine struktūra, kuri liudija svarius babiloniečiu nuopelnus architektūros ir statybos srityje. Šios civilizacijos klestejimo metu Babilonas išaugo i̇ didžiuli miestą su ispūdingais architektūriniais ansambliais. Šis miestas tapo vienu svarbiausiu Artimuju ir Vidurio Rytu tarptautinès prekybos centru, sudètinga sausumos ir upių kelių sistema susijęs su artimais ir tolimais kraštais. Itin svarūs babiloniečiu nuopelnai mokslinio pažinimo srityje: plètodami šumerú paveldą, jie daug dèmesio skyrè ne tik bendram, bet ir vis daugiau specializuotam aukštesnio lygio išsilavinimui. Svariausi babiloniečių laimejimai regimi astronomijos, matematikos, medicinos, teisès, literatūros srityse.

Jie tęsè ir plètojo šumeru mitologijos, religijos, literatūros tradicijas, kuriu siužetai išliko labai panašūs, tik keitėsi pagrindiniu heroju vardai. Lyginant su šumerais, regime poslinkius ir iqvairiose mokslinio pažinimo srityse. Pirmiausia babiloniečiai garsèjo kaip puikūs dangaus kūnų žinovai, astronomai. İdèmiai stebėdami dangaus kūnus, sukūrẻ tikslius pagrindinių žvaigždžių sistemų že- 
mèlapius, sujungè žvaigždes į žvaigždynus ir suteikè jiems pavadinimus, kurie išliko iki nūdienos (pavyzdžiui, Ožiaragis, Jautis, Šaulys).

Kita vertus, stebėdami akivaizdu dangaus kūnų, ypač mènulio, fazių kaitos poveikị augalijai ir gyvūnijos pasauliui, jie perkelia savo stebèjimus ir i žmogaus gyvenimo sriti, kartu klodami vèliau ir kitose civilizacijose išplitusios astrologijos pamatus. Galiausiai iš ju dangaus kūnų stebejjimo ir matematinių skaičiavimų išplaukia metu suskirstymas i 12 mènesiu pagal Mẻnulio fazes, mènesio - $\mathfrak{i} 4$ savaites, savaites $-\mathfrak{i} 7$ paras, paros - $i 24$ valandas. Šis skirstymas nepakitęs išlieka iki nūdienos. Neatsitiktinai rašydamas apie šiuos dalykus Herodotas pripažista, kad ,,saulès laikrodi su rodykle ir 12 dienos valandu Helenai perèmè iš babiloniečių“ (Herodotas 1988: 127). Ir galiausiai, remdamiesi dangaus kūnų išsidèstymu, babiloniečiai orientavosi sausumos ir jūrų kelionèse. Nemažiau svarūs jų nuopelnai ir navigacijos bei kartografijos srityse. Jie, kaip ir šumerai, žinojo jūros kelius ị Indija, kurie vèliau buvo užmiršti, sukūrè pasaulio žemèlapi, kuriame Žemè buvo vaizduojama kaip jūru platybėse esanti sala.

Babilonas taip pat buvo svarbus matematikos, algebros ir geometrijos plètotès židinys. Greta šumeru išrastos šešiasdešimtainès sistemos, jie įveda ir ịvairiose gyvenimo srityse naudoja dešimtainę sistemą. Visoje Artimuju ir Vidurio Rytu civilizacinejje erdvëje babiloniečiai garsèja savo pasiekimais medicinos srityje, kuri jau buvo pasiekusi toki diferenciacijos lygi, kai medikai specialistai specializavosi konkrečiu ligu - chirurgijos, odos, vidaus organu, akiu ir pan. srityse. Gydytojai daro sudètingas operacijas, gydo ivvairias akiu, ausu, odos, inkstu, nervų ir širdies ligas.

Pirmieji sudare isstatymų sąvadą XVIII a. pr. m. e. Hamurabio teisynas sudarytas iš 282 istatymų, kurie buvo paremti pamatiniu babiloniečiams principu ",akis už akị, dantis už dantį“. Jie aiškiai apibrèžè įvairių socialinių sluoksnių ir vergu santykius, reguliavo visas pagrindines socialinio gyvenimo sritis, gyné žmones ir nuosavybès teises, apibrèžè pareigas valstybei, reglamentavo pagrindines gyvenimo sritis.Tęsdami šumeru pasiekimus literatūros srityje, jie paliko reikšmingus literatūros ir poetinius mitinius tekstus, iš kurių savo svarba vèlesnèms tautoms išsiskiria „Poema apie pasaulio sukūrimą". Daugelị mūsų paminètų kultūros ir mokslinio pažinimo sričių laimëjimų iš babiloniečiu perèmè senovès graikai.

Kaip ir prieš tai viešpatavę asirai, chaldejjai stato milžiniškus, stulbinančius dydžiu architektūros statinius, iš kuriụ ištaigingumu ir didingumu išsiskiria šventyklos, anksčiau minèto valdovo rūmai. Ju apatinè dalis išliko iki nūdienos ir stebina savo glazūruotu plyteliu dekoru, miestas apjuosiamas ịspūdingomis gynybinèmis sienomis.

Prieštaringa istorinè asmenybè, ik $\mathrm{ku}-$ nijusi griovejo ir statytojo funkcijas, Nabuchodonosaras II, perstato legendiniais tapusi Babelio bokšta, baigia statyti Ištarès vartus ir sukuria vadinamuosius kabančiuosius Semiramidès sodus, apie kuriu gyvavimą žinome iš rašytinių šaltinių. Archeologiniai tyrinejjimai byloja, kad milžiniški Nabuchodonosaro II 
rūmai dydžiu ir ištaigingumu prilygo Asirijos valdovų rūmams. Aptariamu metu reprezentaciniai Babilone statomi pastatai jau buvo puošiami ne fasado reljefais kaip anksčiau, o degtomis ir spalvotai glazūruotomis plytomis: tai matyti iš Ištarès vartu ir Babilono procesiju kelio dekoro ir daugybès kitu objektu, saugomų Luvre bei Britu muziejuje. Daugiau nei tūkstantmeti užsitęsusi Babilono kultūros ir meno viešpatavimo Vidurio Azijos regione periodą sugriauna Persijos karaliaus Kiro vadovaujama kariuomenè, tuo pačiu užbaigdama ilgą šios civilizacijos klestẻjimo ir nuosmukių istoriją.

\section{IŠVADOS}

Vadinasi, po šumeru Mesopotamijos regione išsiskleidusi didinga Babilono civilizacija ne tik perèmè unikalius savo pirmtakų kūrybinius sugebejimus ir išplètojo naujas socialinio, politinio šalies organizavimo ir kultūros formas, kurios savitu pavidalu išsiskleidè urbanizuotoje Babilono kultūroje. Jos kultūros istorija glaudžiai persipina su kita šiaurinèje Mesopotamijos dalyje iškilusia Asirijos kultūra, kadangi ilgą civilizacijos istorijos tarpsni jos permainingai kovojo dèl hegemonijos Mesopotamijos regione. Kita vertus, skirtingai nei šiame regione ankščiau viešpatavę šumerai,

\section{Literatūra}

Herodotas. 1988. Istorija. Vilnius: Mintis.

Margueron J.-C. 2001. Aux origines du plan de Babylone, dans C. Breniquet et C. Kepinski (dir.), Études mésopotamiennes, Recueil de textes offerts à Jean-Louis Huot. Paris, p. 334-336. kurių civilizacija rèmèsi daugelio greta gyvavusių ir tarpusavyje konkuravusių polių sugyvenimu, Babilono civilizacija buvo kitoks valstybinis darinys, kuriame besąlygiškai viešpatavo vienas pagrindinis miestas - Babilonas. Šios civilizacijos kūrejjai pasiekè itin svariu laimejjimu astronomijos, matematikos, teisès, navigacijos, kartografijos, medicinos, urbanizuotos architektūros, literatūros, skulptūros ir kitose srityse. Ju moksliniai ir technologinius išradimai plačiai pasklinda už Mesopotamijos regiono ribų ir smarkiai paveikia tolesnę pasaulio civilizacijos raidą.

McNeill, Hardy William. 1991. The Rise of the West: A History of the Human Community. Chicago: University of Chicago Press. Revised edition. Saggs H. W. F. 1965. Everyday Life in Babylonia and Assyria. Assyrian International News Agency. Senoves Rytu poezija. 1991. Vilnius: Vaga. 